\title{
The relationship between rumen bacterial growth, intake of dry matter, digestible organic matter and volatile fatty acid production in buffalo (Bos bubalis) calves
}

\author{
By U. B. SINGH, D. N. VERMA, A. VARMA AND S. K. RANJHAN \\ Division of Animal Nutrition, Indian Veterinary Research Institute, Izatnagar-243122, \\ $U P$, India
}

(Received 2 June 1976 - Accepted 21 March 1977)

1. The production rates of bacteria in the rumen of buffalo (Bvs bubalis) calves were estimated using an isotope-dilution technique. A series of fifteen experiments was done with animals given green maize and nine experiments with animals given cowpea (Vigna unguiculata).

2. The turnover time ranged from 205 to $567 \mathrm{~min}$ in the group given green maize and from 330 to $648 \mathrm{~min}$ in animals offered cowpea. The production rates of bacteria were (mean $\pm \mathrm{SE} ; \mathrm{g} / \mathrm{d}$ ) $145 \cdot 77 \pm 7.240$ and $237.09 \pm 11.847$ in animais given green maize and cowpea respectively.

3. There was a significant correlation between bacterial production rates and dry matter intake, digestible organic matter and total volatile fatty acids formed in the rumen.

4. Regression equations obtained for the two foodstuffs were different suggesting that the bacterial growth rate may vary depending upon the quantity and quality of foodstuff digested and possibly the ratio nitrogen: energy of the foodstuff.

Ruminants meet their protein or amino acid requirements from the dietary proteins and rumen micro-organisms which leave the rumen and are digested in the small intestine. These micro-organisms can degrade dietary proteins and may utilize some of the degradation products for their own protein synthesis. Microbes in the rumen can also utilize nonprotein nitrogenous compounds and can convert dietary proteins of low biological value into microbial proteins which are of higher biological value (Bergen, Purser \& Cline, 1967). It is important to know the extent of microbial growth for any particular dietary regimen in order to assess its effectiveness for animal production.

In vitro and in vivo experiments have been done to estimate microbial growth in the rumen. In vitro techniques (Henderickx, 1959, 1961; Walker \& Nadar, 1968; Van Nevel, Demeyer \& Henderickx, 1974) and theoretical calculations (Hungate, 1966; Baldwin, Lucas \& Cabrera, 1970; Forrest \& Walker, 1971; Leng 1972) have been used by many workers. The validity of both in vitro and theoretical values will depend upon their confirmation by in vivo experiments. Attempts were made by various workers to estimate microbial protein synthesis in vivo using ${ }^{15} \mathrm{~N}$ (Mathison \& Milligan, 1971) and ${ }^{35} \mathrm{~S}$ (Roberts \& Miller, 1969; Harrison, Beever \& Thomson, 1972; Singh, Varma, Verma, Lal \& Ranjhan, 1973; Singh, Verma, Varma \& Ranjhan, $1974 a, 1974 b$ ) and ${ }^{14} \mathrm{C}$ (Singh, Varma, Verma \& Ranjhan, 1974). Different markers, e.g. nucleic acids (Smith, 1969; Smith \& McAllan, 1971), diaminopimelic acid (DAPA) (Hutton, Bailey \& Annison, 1971; Singh, Verma, Varma \& Ranjhan, 1976) and vitamin $B_{12}$ (Weller, Gray \& Pilgrim, 1958), have been used to assess microbial protein synthesis in the rumen. The results of several studies involving twenty-seven diets and utilizing DAPA as a bacterial marker for bacterial cell growth in the rumen have been reviewed by Thomas (1973). The cell yield varied from 15.3 to $51 \cdot 1 \mathrm{~g} \mathrm{~N} / \mathrm{kg}$ organic matter fermented.

The bacterial growth is variable and may be influenced by the nature of the microorganisms, type of substrate in the rumen and the dilution rate (Hogan \& Weston, 1971; Thomas, 1973). This paper describes a detailed study of in vivo estimations of bacterial 
production rates in the rumen, using an isotope-dilution technique with ${ }^{14} \mathrm{C}$ and ${ }^{35} \mathrm{~S}$, for two different foodstuffs and also determination of the relationship between bacterial production and dry matter (DM) intake, digestible organic matter (DOM) and volatile fatty acid (VFA) production.

\section{EXPERIMENTAL}

\section{Animals and feeding regimen}

Three male Murrah buffaloes (Bos bubalis) approximately 2 years of age, each fitted with a rumen cannula, were used in these studies. The animals were housed singly in metabolism cages. In the first series of experiments each animal was given $15-20 \mathrm{~kg}$ chopped green maize (Zea mays L. var. Ganga hybrid 2) daily, whereas in the second series of experiments 25-30 kg cowpea (Vigna unguiculata)/d was fed to each animal. The amount of uneaten food was measured to estimate intake. The calves were subjected to a pre-experimental feeding period of 5 weeks during which they received their ration once daily, and thereafter they received their daily ration in twelve equal amounts at $2 \mathrm{~h}$ intervals for a period of 3 weeks. The ration remaining, if any, at the end of each $2 \mathrm{~h}$ period was removed and weighed. The samples of the food offered and the uneaten food were collected daily for analysis. Digestibility trials of $7 \mathrm{~d}$ duration were also done to estimate DoM. The analysis of food and faeces was done according to the methods of the Association of Official Agricultural Chemists (1960).

\section{Estimations of VFA production rates}

VFA production rates were estimated by the single-injection isotope-dilution technique as described previously (Chaturvedi, Singh \& Ranjhan, 1973).

\section{Preparation of labelled mixed bacteria}

Rumen bacteria from the experimental calves were labelled either with ${ }^{35} \mathrm{~S}$ or ${ }^{14} \mathrm{C}$ by in vitro incubation as described previously (Singh, Verma et al. 1974b).

The bacterial suspension was injected as a single dose into the rumen through the cannula. During administration of the dose the contents of the rumen were thoroughly mixed manually by inserting an arm through the cannula.

Samples from the rumen were taken at various intervals for a period of $9 \mathrm{~h}$, from four different sites. The samples were freed of large particulate matter using specially-built probes covered with fine nylon gauge as described previously (Chaturvedi et al. 1973). The rumen fluid samples $(35 \mathrm{ml})$ were transferred to a cold vessel $\left(4^{\circ}\right)$ and were analysed immediately (Singh, Verma et al. 1974b).

\section{Sampling and analytical procedure for bacterial cells}

For both series of experiments the specific radioactivity was expressed as disintegrations/ min per $\mathrm{mg}$ dry mixed cells. The rumen organisms were withdrawn and analysed, and the radioactivity in the bacterial fraction was determined for the calculations of production rates as described previously (Singh, Verma et al. 1974b).

\section{RESULTS}

The results obtained from different experiments are presented in Tables 1 and 2. Analyses of variance were performed to compare the variations between animal and within animals. It was observed that variations between animals were not different from the variations within animals in the case of DM intake with both the feeding regimens, and for bacteria 
Table 1. Production rates of bacteria and volatile fatty acids $(V F A)$ in the rumen of buffalo (Bos bubalis) calves given green maize

\begin{tabular}{|c|c|c|c|c|c|c|c|c|c|}
\hline $\begin{array}{l}\text { Animal } \\
\text { no. }\end{array}$ & $\begin{array}{c}D M \\
\text { intake } \\
(g)\end{array}$ & $\begin{array}{c}\text { DOM } \\
(\mathbf{g})\end{array}$ & $\begin{array}{c}\text { Isotope } \mathrm{g} \\
\text { used }\end{array}$ & $\begin{array}{l}\text { Dose of } \\
\text { isotope } \\
\text { (disinte- } \\
\text { grations } / \mathrm{min} \\
\left(\times 10^{6}\right)\end{array}$ & $\begin{array}{l}\text { Specific } \\
\text { radio- } \\
\text { activity } \\
\text { at zero } \\
\text { time (dis- } \\
\text { integrations/ } \\
\text { min per mg } \\
\text { dry cells) }\end{array}$ & $\begin{array}{l}\text { Pool } \\
\text { size } \\
(\mathrm{g})\end{array}$ & $\begin{array}{c}\text { Turnover } \\
\text { time } \\
\text { (min) }\end{array}$ & $\begin{array}{c}\text { Bacteria } \\
\text { production } \\
\text { rate } \\
(\mathbf{g} / \mathrm{d})\end{array}$ & $\begin{array}{c}\text { Total } \\
\text { VFA } \\
(\mathrm{mol} / \mathrm{d})\end{array}$ \\
\hline $\begin{array}{l}1 \\
2 \\
3 \\
1 \\
2 \\
3 \\
1 \\
2 \\
3 \\
1 \\
2 \\
3 \\
1 \\
2 \\
3\end{array}$ & $\begin{array}{l}3158 \\
2737 \\
3087 \\
2543 \\
2940 \\
3335 \\
2248 \\
3256 \\
2856 \\
2110 \\
2543 \\
2614 \\
2199 \\
2600 \\
2650\end{array}$ & $\left.\begin{array}{l}2001 \\
1593 \\
1797 \\
1484 \\
1644 \\
2024 \\
1509 \\
1852 \\
1662 \\
1232 \\
1422 \\
1556 \\
1284 \\
1454 \\
1608\end{array}\right\}$ & $\begin{array}{l}{ }^{14} \mathrm{C} \text {-labelled } \\
\text { bacteria }\end{array}$ & $\begin{array}{r}17 \cdot 56 \\
18 \cdot 29 \\
10 \cdot 69 \\
33 \cdot 20 \\
33 \cdot 20 \\
33 \cdot 20 \\
172 \cdot 12 \\
140 \cdot 78 \\
148 \cdot 59 \\
115 \cdot 58 \\
115 \cdot 58 \\
115 \cdot 58 \\
425 \cdot 24 \\
425 \cdot 24 \\
425 \cdot 24\end{array}$ & $\begin{array}{r}295 \\
159 \\
204 \\
912 \\
1000 \\
955 \\
4677 \\
4467 \\
4169 \\
3090 \\
3020 \\
2884 \\
10230 \\
10470 \\
10470\end{array}$ & $\begin{array}{l}59 \cdot 50 \\
57 \cdot 70 \\
52 \cdot 37 \\
36 \cdot 40 \\
33 \cdot 20 \\
34 \cdot 76 \\
36 \cdot 80 \\
31 \cdot 51 \\
35 \cdot 64 \\
37 \cdot 40 \\
38 \cdot 27 \\
40 \cdot 07 \\
39 \cdot 70 \\
40 \cdot 61 \\
40 \cdot 61\end{array}$ & $\begin{array}{l}531 \cdot 36 \\
567 \cdot 36 \\
453 \cdot 60 \\
338 \cdot 40 \\
324 \cdot 00 \\
305 \cdot 28 \\
345 \cdot 60 \\
309 \cdot 60 \\
292 \cdot 75 \\
468 \cdot 00 \\
410 \cdot 40 \\
396 \cdot 00 \\
550 \cdot 08 \\
455 \cdot 04 \\
432.00\end{array}$ & $\begin{array}{l}161 \cdot 25 \\
146 \cdot 44 \\
166 \cdot 24 \\
154 \cdot 80 \\
147 \cdot 40 \\
164 \cdot 00 \\
153 \cdot 34 \\
146 \cdot 58 \\
175 \cdot 31 \\
115 \cdot 00 \\
134 \cdot 40 \\
145 \cdot 00 \\
108 \cdot 70 \\
128 \cdot 30 \\
135 \cdot 40\end{array}$ & $\begin{array}{l}18 \cdot 11 \\
16 \cdot 14 \\
20 \cdot 50 \\
17 \cdot 45 \\
16 \cdot 15 \\
20 \cdot 48 \\
17 \cdot 24 \\
16 \cdot 13 \\
20 \cdot 49 \\
14 \cdot 00 \\
15 \cdot 49 \\
16 \cdot 04 \\
12 \cdot 89 \\
14 \cdot 28 \\
15 \cdot 49\end{array}$ \\
\hline $\begin{array}{l}\text { Average } \\
\text { SE }\end{array}$ & $\begin{array}{r}2725 \cdot 06 \\
165 \cdot 24\end{array}$ & $\begin{array}{r}1608 \cdot 1 \\
88 \cdot 6\end{array}$ & & & & & & $\begin{array}{r}145 \cdot 477 \\
7 \cdot 240\end{array}$ & $\begin{array}{r}16 \cdot 725 \\
1.036\end{array}$ \\
\hline
\end{tabular}

DM, dry matter; DOM, digestible organic matter.

Table 2. Production rates of bacteria and volatile fatty acids (VFA) in the rumen of buffalo (Bos bubalis) calves given cowpea (Vigna unguiculata)

\begin{tabular}{|c|c|c|c|c|c|c|c|c|c|}
\hline $\begin{array}{c}\text { Animal } \\
\text { no. }\end{array}$ & $\begin{array}{c}\text { DM } \\
\text { intake } \\
\text { (g) }\end{array}$ & $\begin{array}{c}\text { DOM } \\
(\mathrm{g})\end{array}$ & $\begin{array}{l}\text { Isotope } \\
\text { used }\end{array}$ & $\begin{array}{c}\text { Dose of } \\
\text { isotope } \\
\text { (disinte- } \\
\text { grations/ } \\
\text { min } \\
\left(\times 10^{6}\right)\end{array}$ & $\begin{array}{l}\text { Specific } \\
\text { radio- } \\
\text { activity } \\
\text { at zero } \\
\text { time (dis- } \\
\text { integrations/ } \\
\text { min per mg } \\
\text { dry cells) }\end{array}$ & $\begin{array}{c}\text { Pool } \\
\text { size } \\
(\mathrm{g})\end{array}$ & $\begin{array}{c}\text { Turnover } \\
\text { time } \\
\text { (min) }\end{array}$ & $\begin{array}{l}\text { Bacteria } \\
\text { production } \\
\text { rate } \\
(\mathrm{g} / \mathrm{d})\end{array}$ & $\begin{array}{c}\text { Total } \\
\text { VFA } \\
\text { (mol/d) }\end{array}$ \\
\hline $\begin{array}{l}1 \\
2 \\
3 \\
1 \\
2 \\
3 \\
1 \\
2 \\
3\end{array}$ & $\begin{array}{l}4350 \\
3570 \\
3625 \\
4161 \\
3661 \\
3973 \\
3919 \\
3588 \\
3315\end{array}$ & $\left.\begin{array}{l}2632 \\
2096 \\
2073 \\
2518 \\
2150 \\
2273\end{array}\right\}$ & $\begin{array}{l}{ }^{35} \text { S-labelled } \\
\text { bacteria }\end{array}$ & $\begin{array}{r}6 \cdot 58 \\
6 \cdot 58 \\
85 \cdot 58 \\
58 \cdot 19 \\
58 \cdot 19 \\
6 \cdot 58 \\
1.07 \\
1 \cdot 34 \\
1.34\end{array}$ & $\begin{array}{r}67 \cdot 9 \\
93 \cdot 3 \\
1698 \cdot 0 \\
660 \cdot 7 \\
831 \cdot 8 \\
85 \cdot 5 \\
12 \cdot 1 \\
16 \cdot 2 \\
13 \cdot 5\end{array}$ & $\begin{array}{l}96.97 \\
70 \cdot 56 \\
50.40 \\
88 \cdot 08 \\
69 \cdot 96 \\
68.95 \\
88 \cdot 50 \\
82.59 \\
99 \cdot 38\end{array}$ & $\begin{array}{l}527 \cdot 04 \\
440 \cdot 64 \\
330 \cdot 76 \\
504.00 \\
479.52 \\
422 \cdot 49 \\
479.52 \\
505 \cdot 00 \\
648.00\end{array}$ & $\begin{array}{l}264 \cdot 94 \\
230 \cdot 58 \\
219 \cdot 43 \\
251 \cdot 66 \\
210 \cdot 09 \\
235 \cdot 02 \\
265 \cdot 78 \\
235 \cdot 52 \\
220 \cdot 86\end{array}$ & $\begin{array}{l}21 \cdot 60 \\
18 \cdot 37 \\
16 \cdot 52 \\
21 \cdot 60 \\
16 \cdot 52 \\
18 \cdot 37 \\
20 \cdot 60 \\
19 \cdot 37 \\
17 \cdot 62\end{array}$ \\
\hline $\begin{array}{l}\text { Average } \\
\text { SE }\end{array}$ & $\begin{array}{c}3795.77 \\
190.023\end{array}$ & $\begin{array}{r}2316.7 \\
140.3\end{array}$ & & & & & & $\begin{array}{c}237.09 \\
11.847\end{array}$ & $\begin{array}{r}18.95 \\
1 \cdot 165\end{array}$ \\
\hline
\end{tabular}

DM, dry matter; DOM, digestible organic matter. 
production in the group given cowpea, and therefore, mean squares based on total observations were used for the calculation of the standard error. The variations between animals were significantly greater than variations within animals for bacteria production in green maize and consequently in such cases values for mean squares between animals were used to calculate the standard error. The pool size of dry bacterial cells varied from 31.5 to $59.5 \mathrm{~g}$ and 54.4 to $99.4 \mathrm{~g}$ in animals given green maize and cowpea respectively. The mean $( \pm \mathrm{SE})$ production rates of bacterial cells $(\mathrm{g} / \mathrm{d})$ and total VFA $(\mathrm{mol} / \mathrm{d})$ respectively were $145.477 \pm 7.240$ and $16.725 \pm 1.036$ with green maize, and $237.090 \pm 11.847$ and $18.950 \pm 1 \cdot 169$ with cowpea.

The relationships between bacteria production and the DM intake, DOM and total VFA produced were derived. Analysis of variance was performed to test the difference between the individual animals in both slope and displacement of the respective regression lines. It was observed that the regressions for individual animals did not differ in slope or displacement except in the case of total VFA in the green maize-fed group $(P<0.05)$. Therefore, the regression equations based on all observations were obtained for all measurements except total VFA for the green maize-fed group. In the latter case the regression equation was determined separately for each animal. The bacteria production $(Y ; \mathrm{g} / \mathrm{d})$ was significantly $(P<0.01)$ related to the DM intake $(X ; \mathrm{g} / \mathrm{d})$. The regression equations of the relationship were:

for green maize-fed group: $Y=53 \cdot 37+0 \cdot 0338 X(\mathrm{SE} \pm 0.0099)$

for cowpea-fed group: $Y=59.83+0.0467 X$ (SE \pm 0.0146$)$

DOM was related to the growth of bacteria in the rumen $(P<0.01)$. The relationships between DOM $(x ; \mathrm{g} / \mathrm{d})$ and dry bacterial cells $(Y ; \mathrm{g} / \mathrm{d})$ were as follows:

for green maize-fed group: $Y=48 \cdot 1852+0.0605 x$ (SE \pm 0.0146$)$

for cowpea-fed group: $Y=51 \cdot 7556+0.0800 x(\mathrm{SE} \pm 0.0104)$

Statistically significant $(P<0.01)$ relationships were also derived between the growth of rumen bacteria $(Y ; \mathrm{g} / \mathrm{d})$ and the production of total VFA $(X ; \mathrm{mol} / \mathrm{d})$ as follows:

for cowpea-fed group: $Y=58 \cdot 3748+9 \cdot 4302 X(\mathrm{sE} \pm 1 \cdot 3369)$

for green maize-fed group: animal no. 1: $Y_{1}=-29 \cdot 7383+10 \cdot 5632 X(\mathrm{sE} \pm 0 \cdot 5074)$

animal no. $2: Y_{2}=-20 \cdot 2235+10 \cdot 2857 X(\mathrm{SE} \pm 1 \cdot 9013)$

animal no. $3: Y_{3}=44 \cdot 51312+6 \cdot 0579 X(\mathrm{SE} \pm 1 \cdot 0632)$.

\section{DIS CUSSION}

In ruminants, food proteins are degraded into amino acids by rumen microbes as soon as they reach the rumen. This is one of the major reasons why simple isotope-dilution techniques could not be applied for measuring the microbial protein synthesis in vivo, because if labelled protein is used as a marker it may not remain as such after it enters the rumen. In our earlier studies (Singh, Verma et al. 1974a,b), this problem has been avoided by using labelled microbial cells of rumen origin from animals kept on the same dietary regimen.

In these experiments the animals were given their ration at $2 \mathrm{~h}$ intervals to obtain a steadystate in the metabolic processes in the rumen. The synthesis of microbial cells would, therefore, be a continuous process during the period of frequent feeding and the values could be extrapolated to a $24 \mathrm{~h}$ period.

The production rate of bacteria varied from 109 to $265 \mathrm{~g} / \mathrm{d}$ (Tables 1 and 2). This variation was due to differences in the foodstuff and the quantities of rations consumed by the individual animals. There was a linear relationship between the growth of bacteria 
in the rumen and the DM intake of the animals. A similar correlation was observed between the DOM and the amount of dry bacterial cells produced daily. In the present experiments the average bacterial cell yield was approximately 107 and $132 \mathrm{~g} / \mathrm{kg}$ DOM in animals given green maize and cowpea respectively. In previous experiments in which a concentrate ration together with chopped wheat straw was fed to the animals, a bacterial cell yield of $137 \mathrm{~g} / \mathrm{kg}$ DOM was obtained (Singh, Verma et al. 1974b). Leng (1972) has proposed a higher yield of rumen bacterial cells, expressed per $100 \mathrm{~g}$ DOM, on the basis of theoretical calculations. Most of the stoicheiometric reactions are based on the assumptions that (1) the fermentation is exclusively anaerobic, (2) VFA, carbon dioxide and methane are the only endproducts of fermentation, and (3) other hydrogen-consuming reactions such as fatty acid hydrogenation are normally not so important and can be neglected. It is possible that hydrogen, ethanol, lactic acid and formic acid formed in the process of fermentation may be important in some cases and should be taken into account. There is increasing evidence that bacterial cell growth is variable and influenced by the nature of the micro-organisms, availability of energy-yielding substrate (namely carbohydrates), utilizable $\mathrm{N}$ compounds or other growth factors in the rumen and the dilution rate (El-Shazly \& Hungate, 1965; Hogan \& Weston, 1971; Thomas, 1973). The results of many studies using DAPA as a bacterial marker for bacterial cell growth in the rumen have been summarized in a review by Thomas (1973). The cell yield varied from $15 \cdot 3$ to $51 \cdot 1 \mathrm{~g} \mathrm{~N} / \mathrm{kg}$ organic matter fermented. The values are based on different studies using a range of twenty-seven diets. It appears from the results that the extent of protein synthesis is not constant. On the basis of these results the prediction of cell yield, unless supported by direct measurements on similar animals maintained on identical feeding regimens, has been questioned (Annison, 1974). El-Shazly \& Hungate (1965), from the 'zero-time rate' method of estimating microbial growth, observed that the net microbial growth rate is usually, if not always, much less than would be possible under ideal growth conditions. The quantity of proteins leaving the rumen may change suddenly on grain-based diets (Ishaque, Thomas \& Rook, 1971; Jackson, Rook \& Towers, 1971). This change was associated with a large change in the VFA pattern in the rumen, in which there was a change from a high-propionic-producing system to a high-acetate-producing system (Edie \& Mann, 1970; Jackson et al. 1971). This suggests that the efficiency of synthesis of proteins by the micro-organisms in the rumen varies depending on the composition of the food and microbial community. There appears to be a greater protein synthesis rate in the rumen of sheep on diets that produce a high-propionate fermentation pattern (Hume, 1970).

The bacterial growth in our experiments is much lower than the generally accepted value of $30 \mathrm{~g}$ bacteria formed/mol VFA produced. We have observed $76 \mathrm{~g}$ bacteria growth/d when $3 \mathrm{~mol}$ VFA are produced in goats given Berseem (Trifolium alexandrinum) (unpublished observations). In a situation where about 3 to 4 mol VFA are produced in the rumen the value of about $30 \mathrm{~g}$ microbes/mol VFA fits in the equation.

In the present studies, linear relationships were observed between the rate of growth of rumen bacterial cells and other measurements e.g. DM intake, DoM and VFA. These studies were based on animals given rations in amounts within a narrow range. It is difficult to extrapolate beyond the experimentally obtained range since it is not certain whether the linear relationship may be obtained in animals with a wide range of intake.

The authors thank Dr C. M. Singh for facilities and encouragement. Shri S. B. Johri and Shri U.S. Srivastava gave competent technical assistance. 


\section{REFERENCES}

Annison, E. F. (1974). In Trace' Studies on Non-protein Nitrogen for Ruminants, vol. 2, p. 141. Vienna: International Atomic Energy Agency.

Association of Official Agricultural Chemists (1960). Official Method of Analysis, 9th ed. Washington, DC.

Baldwin, R. L., Lucas, H. L. \& Cabrera, R. (1970). In Ply'siology of Digestion and Metabolism in the Ruminatt, p. 319 [A. T. Phillipson, editor], Newcastle on Tyne: Oriel Press.

Bergen, W. G., Purser, D. B. \& Cline, J. H. (1967). J. Nutr. 92, 357.

Chaturvedi, M. L., Singh, U. B. \& Ranjhan, S. K. (1973). J. agric. Sci., Camb. 80, 393

Edie, J. M. \& Mann, S. O. (1970). In Physiology of Digestion and Metabolism in the Ruminant, p. 335. [A. T. Phillipson, editor], Newcastle on Tyne: Oriel Press.

El-Shazly, K. \& Hungate, R. E. (1965). Appl. Microbiol. 13, 62.

Forrest, W. W. \& Walker, D. J. (1971). In .Advances in Microbial Physiology, p. 213 [J. N. Wilkinson and A. H. Rose, editors]. New York: Academic Press.

Harrison, D. G., Beever, D. E. \& Thomson. D. J. (1972). Proc. Nutr. Soc. 31, 60A.

Henderickx, H. K. (1959). Diergeneesk. Tijdschr. 28, 80.

Henderickx, H. K. (1961). Archs int. Physiol. Biochem. 69, 449.

Hogan, J. P. \& Weston, R. H. (1971). Allst. J. agri', Re's. 22. 951.

Hume, I. D. (1970). Aust. J. agric. Res. 21, 297.

Hungate, R. E. (1966). In The Rumen and its Miciobes, p. 319. New York: Academic Press.

Hutton, K., Bailey, F. J. \& Annison, E. F. (1971). Br. J. Nuti. 25, 165.

Ishaque, M., Thomas, P. C. \& Rook, J. A. F. (1971). Nature, New Biol. 231, 253.

Jackson, P., Rook, J. A. F. \& Towers, K. G. (1971). J. Dairy Res. 38, 33.

Leng, R. A. (1972). In Chemistry and Biochemistry of Herbage [R. W. Bailey and G. W. Butler, editors]. New York: Academic Press.

Mathison, G. W. \& Milligan, L. P. (1971). Br. J. Nutr. 23, 585.

Roberts, S. A. \& Miller, E. L. (1969). Proc. Nutr. Soc. 28, 32A.

Singh, U. B., Varma, A., Verma, D. N., Lal. M. \& Ranjhan, S. K. (1973). J. agric. Sci., Camb. 81, 349.

Singh, U. B., Varma, A., Verma, D. N. \& Ranjhan, S. K. (1974). J. Dairy Res. 41, 299.

Singh, U. B., Verma, D. N., Varma, A. \& Ranjhan, S. K. (1974a). Indian J. Anim. Sci. 44, 89.

Singh, U. B., Verma, D. N., Varma, A. \& Ranjhan, S. K. (1974b). J. agric. Sci., Camb. 83, 13.

Singh. U. B., Verma, D. N., Varma, A. \& Raujhan, S. K. (1976). In Tracer Studies on Non-protein Nitrogen for Ruminants, vol. 3, p. 103. Vienna: International Atomic Energy Agency.

Smith R. H. (1969). J. Dairy Res. 36, 313.

Smith R. H. \& McAllan, A. B. (1971). Br. J. Nutr. 25, 181.

Thomas, P. C. (1973). Proc. Nutr. Soc. 32, 85.

Van Nevel, C. J., Demeyer, D. 1. \& Henderickx, H. K. (1974). In Tracer Studies on Non-protein Nitrogen for Ruminants, vol. 2, p. 15. Vienna: International Atomic Energy Agency.

Walker, D. J. \& Nadar, C. J. (1968). 4ppl. Microbiol. 16, 1124.

Weller, R. A., Gray, V. F. \& Pilgrim, A. F. (1958). Br. J. Nutr. 12. 421. 